\title{
MUHAMMADIYAH DALAM GERAKAN SOSIAL DI KABUPATEN WAJO
}

\author{
Andi Agustang; Hidayah Quraisy; Andi Asrifan
}

\begin{abstract}
ABSTRAK
Jenis penelitian ini merupakan penelitian kualitatif deskriptif dengan pendekatan partisipatoris. Pendekatan ini diharapkan peneliti dapat mengungkap pengalaman, persepsi dan gagasan yang mendalam mengenai: (1) perkembangan organisasi Muhammadiyah, (2) bentuk gerakan sosial Muhammadiyah, dan (3) transformasi sosial Muhammadiyah di Kabupaten Wajo. Penelitian ini difokuskan pada gerakan sosial Muhammadiyah, termasuk perkembangan ideologi dan transformasi sosial Muhammadiyah, dengan lokus penelitian di Kabupaten Wajo Provinsi Sulawesi Selatan. Hasil Penelitian ini menunjukkan, bahwa Perkembangan organisasi Muhammadiyah di Kabupaten Wajo mengalami proses perkembangan yang stagnasi. Struktur organisasi yang tidak dinamis serta semangat pastabiqul khaerat mulai melemah. Bentuk kegiatan Muhammadiyah dapat dikelompokkan ke dalam tiga bidang, yakni: (1) bidang keagamaan yang meliputi memberikan tuntunan dan pedoman dalam bidang aqidah, ibadah, akhlak dan muamalah berdasarkan alquran dansunnah, mendirikan masjid dan mushalla sebagai tempat sarana ibadah, mencetak kader ulama (fuqaha), menelaah berbagai kajian keislaman dan perkembangan umat islam, memberi fatwa dan tuntunan dalam bidang keagamaan dan melakukan dakwah, (2) bidang pendidikan yang meliputi pendidikan yang beroerientasi kepada perpaduan antara sistem pendidikan umum dan sistem pesantren, dan (3) bidang sosial kemasyarakatan yang meliputi kegiatan dalam bentuk amal usaha, balai pengobatan, panti asuhan anak yatim. Namun demikian, tidak dapat dipungkiri ketiga gerakan sosial yang selanjutnya menjadi amal usaha Muhammadiyah mengalami keterpurukan dalam beberapa tahun terakhir. Gerakan sosial Muhammadiyah di kabupaten Wajo dalam bidang sosial kemasyarakatan belum optimal menyentuh pemberdayaan masyarakat jika ditinjau dari pelaksanaan program kerja. Adapun dampak dari gerakan Muhammadiyah terhadap proses transformasi sosial masyarakat di Kabupaten Wajo, terutama yang terkait dengan tahayul, bidah dan khurafat, masyarakat Wajo pada umumnya dan warga Muhammadiyah pada khususnya lebih berpikir rasional dalam menyikapi hidup ini sesuai dengan alquran dan Sunnah. Dalam bidang pendidikan, telah banyak mengubah paradigma berpikir msyarakat. Dari cara berpikir yang negatif atau sempit berubah menjadi berpikir positif dan luas terhadap dunia pendidikan. Akan tetapi proses transformasi juga sudah mulai melemah.
\end{abstract}

\section{A. INTRODUCTION}

Kiai Haji Ahmad Dahlan mendirikan Persyarikatan Muhammadiyah pada tahun 1912, kondisiumat Islam pada waktu itu dalam keadaan sangat terpuruk, dan terbelakang dengan tingkat pendidikan yang sangat rendah kemakmuran dan ekonomi yang parah serta kemampuan politis yang tidak berdaya. Lebih memperihatinkan lagi identitas keislaman merupakan salah satu poin negatif, di mana kehidupan umat Islam ketika itu identik dengan profil kaum santri yang selalu mengurusi kehidupan akhirat semata, sementara tidak tahu dan tidak mau tahu dengan perkembangan zaman. Sementara lembaga organisasi keagamaan juga masih berkelut dengan urusan yang tidak banyak bersentuhan dengan dinamika realitas sosial apalagi berusaha untuk memajukan.

Ajaran Islam seakan menjadi belenggu yang semakin membenamkan umatnya kepada situasi yang tidak berharga dan tidak berdaya, disisi lain kelompok masyarakat yang terdidik menjadi alergi dengan Islam dan kaum muslim karena dianggap sebagai sumber keterbelakangan masyarakat dan tidak bisa dijadikan jalan untuk membangun masa depan yang lebih baik. 
Prinsip utama gerakan Muhammadiyah merupakan hasil pemahaman terhadap ajaran islam yang termaktub dalam al-Qur'an dan as-sunnah hasil pemahaman demikian dirumuskan sebagai pola kelakuan perjuangan Muhammadiyah yang kemudian mendorong memberi arah dan bentuk setiap aktifitas Muhammadiyah, keseluruhan dari prinsip perjuangan Muhammadiyah dapat dikelompokan menjadi lima prinsip Islam, yaitu :

Pertama, Muhammadiyah sebagai gerakan tajdid terus mendorong tumbuhnya gerakan pemurnian ajaran Islam dalam masalah yang baku (al-tsawabit) dan pengembangan pemikiran dalam masalah-masalah ijtihadiyah yang menitikberatkan aktivitasnya pada dakwah amar makruf nahi mungkar ; Kedua, Muhammadiyah sebagai gerakan Islam dengan semangat tajdid yang dimilikinya terus mendorong tumbuhnya pemikiran Islam secara sehat dalam berbagai bidang kehidupan. Pengembangan pemikiran Islam yang berwatak tajdid tersebut sebagai realisasi dari ikhtiar mewujudkan risalah Islam sebagai rahmatan lil-alamin yang berguna dan fungsional bagi pemecahan permasalahan umat, bangsa, negara, dan kemanusiaan dalam tataran peradaban global ; Ketiga, sebagai salah satu komponen bangsa, Muhammadiyah bertanggung jawab atas berbagai upaya untuk tercapainya cita-cita bangsa dan Negara Indonesia, sebagaimana dituangkan dalam Pembukaan Konstitusi Negara ; Keempat, sebagai warga dunia Islam, Muhammadiyah bertanggung jawab atas terwujudnya kemajuan umat Islam di segala bidang kehidupan, bebas dari ketertinggalan, keterasingan, dan keteraniayaan dalam percaturan dan peradaban global ; Kelima, sebagai warga dunia, Muhammadiyah senantiasa bertanggungjawab atas terciptanya tatanan dunia yang adil, sejahtera, dan berperadaban tinggi sesuai dengan misi membawa pesan Islam sebagai rahmatan lilalamin.

Di kabupaten Wajokegiatan dakwah Muhammadiyah dimulai sejak tahun 1926. Hal tersebut dapat ditelusuri dalam Sejarah Muhammadiyah Sulawesi Selatan. Muhammadiyah telah eksis di Kabupaten Wajo khususnya di Sengkang dan Belawa. Termasuk organisasi sosial paling tua di antara organisasi sosial yang lainnya. Semangat juang dari para pedagang mengembangkan Muhammadiyah ditandai dengan amal usaha seperti pendidikan, panti sosial, dan ekonomi.Dari aspek pendidikan melahirkan Sekolah Dasar (SD) dan atauMadrasah Ibtidaiyah (MI), SMP (MTS), SMA (MA) bahkan Perguruan Tinggi.

\section{B. THEORETICAL FRAME WARK}

\section{Sejarah Gerakan Sosial}

Teori perkembangan sejarah melukiskan proses historis mempunyai logika, makna atau bentuk khusus dan mengalami kemajuan menurut cara tertentu sesuai dengan "hukum besi" sejarah. Maka teori ini memandang gerakan sosial semata sebagai simpson atau fenomena perubahan sosial yang terus-menerus.Gerakan muncul dilihat sebagai "sakit demam" di saat krisis sosial atau sebagai terobosan revolusioner.Penyebab perubahan sosial sebenarnya terdapat di dalam kebutuhan historis sendiri.

Gerakan sosial dinilai sebagai sebuah bentuk aktivitas yang khas dari masyarakat sipil.Dalam gerakan sosial, aktor-aktor terlibat secara mandiri dan diikat oleh suatu identitas kolektif yang dibangun atas dasar kebutuhan dan kesadaran untuk keterhubungan (connectedness) (Diani and Bison, 2004).

\section{Tipologi Gerakan Sosial}

Gerakan sosial memiliki ragam dan tipe gerakan yang variatif.Gerakan sosial bisa mengakomodir dan memobilisiasi partisipan dengan jumlah yang sangat terbatas, ratusan, ribuan atau bahkan jutaan orang.Gerakan sosial bisa bergerak dalam lingkup dan batas-batas legalitas yang jelas pada suatu masyarakat, juga bisa pula bergerak secara ilegal sebagai gerakan 'bawah tanah' (underground groups)(Sujatmiko, 2016).

Klandemans dalam Suharko (2006) membagi gerakan sosial menjadi dua tipe, yaitu : (1) proactive social movement (pergerakan sosial proaktif); (2) reactive social movement (pergerakan sosial reaktif). Pergerakan sosial proaktif merupakan suatu jenis 
gerakan sosial yang muncul karena adanya suatu kondisi tertentu di dalam kehidupan masyarakat yang tidak dapat ditolerir, dan tujuan mereka adalah untuk mempromosikan perubahan sosial.Sedangkan pergerakan sosial reaktif ialah gerakan yang muncul karena kondisi tertentu dalam masyarakat mengalami perubahan, dan masyarakat memberikan reaksi uuntuk menolak perubahan tersebut (Henslin, 2006).

Tipe gerakan sosial lainnya dikemukakan oleh David Aberle (1966), yang mengklasifikasikan gerakan sosial menjadi empat tipe berdasarkan besarnya perubahan sosial yang dikehendaki dan tipe perubahan sosial yang dikehendaki.

Tipe pertama, Alternative Movements, yaitu suatu gerakan sosial yang berusaha mengubah sebagian perilaku orang. Sebagai contoh gerakan sosial dari Women Christian Temprerance Union pada kurun waktu 1990-an yang bertujuan mengubahperilaku orang untuk berhenti minum minuman beralkohol. Para anggotanya yakin jika mereka dapat menutup tempat minuman keras, masalah seperti kemiskinan dan kekerasan terhadap istri akan hilang. Tipe kedua,Redemptive Movements, yaitu gerakan sosial yang mencoba mengubah perilaku perorangan secara menyeluruh, seperti dalam bidang keagamaan. Tipe ketiga, Reformative Movements, yaitu gerakan sosial yang mencoba mengubah masyarakat namun dengan ruang lingkup yang terbatas,sebagai contoh gerakan persamaan hak kaum perempuan. Tipe keempat, TransformativeMovements, yaitu gerakan yang mencoba mengubah masyarakatsecara menyeluruh seperti gerakan komunis di Kamboja.

\section{Pendekatan Mobilitas Sumber Daya}

Dalam upaya menganalisis dan memahami gerakan sosial padamasyarakat kontemporer, selain dengan mengembangkan pendekatan new social movement (gerakan sosial baru) terdapat pula pendekatanteori mobilisasi sumber daya (Resource Mobilization Theory/RMT). Pendekatan RMT memfokuskan analisisnya pada seperangkat proses kontekstual mengenai pengelolaan sumber daya, dinamika organisasidan perubahan politik, yang membuat gerakan sosial untuk mengoptimalkan potensi-potensi struktural yang dimiliki guna mencapai tujuannya. Pendekatan ini berusaha menganalisis bagaimana para aktor gerakan sosial mengembangkan strategi dan berinteraksi dengan lingkungannya untuk memperjuangkan kepentingan-kepentingan mereka.

Pendekatan teori mobilisasi sumber daya (RMT) memiliki dua model ;model pertama, adalah pendekatan political-interactive model yang dikembangkan oleh Tilly, Gamson, Oberschalldan MC Adam (Canel dalam Sujatmiko, 2002). Pendekatan ini menekankan pentingnya perubahan stuktur kesempatan bagi aksi kolektif, keberadaan jejaring, serta kaitan horizontal yang telah terbangun dengan aggrieved groups (kelompok tertindas) sebagai penentu keberhasilan gerakan sosial. Pendekatan ini juga menempatkan relasi gerakan sosial dengan negara dan sistem politik sebagai salah satu faktor kuat penentu keberhasilan gerakan sosial, misalnya jika suatu negara sistemnya sangat kuat dan represif, maka gerakan sosial akan sangat sulit untuk mencapai tujuannya (Phongpaichit dalam Sujatmiko, 2002).

Model kedua, yaitu organizational-entrepreneurial yang dikembangkan oleh McCarthy dan Zaid.Menurut Zald (1997),model ini memandang bahwa dinamika organisasional, kepemimpinan dan pengelolaan sumberdaya merupakan faktor yang lebih signifikan dalammenentukan keberhasilan gerakan sosial.Model ini mengaplikasikan teori pengembangan organisasi untuk menganalisis gerakan sosial serta menjelaskan bahwasanya organisasi formal merupakan carriers of social movement.Menurut McCarthy dan Zaid, organisasi gerakan sosial adalah suatu organisasi yang kompleks, atau formal, yang mengidentikkan tujuannya dengan preferensi dari gerakan sosial dan berusaha mewujudkan pencapaian tujuan-ujuan tersebut.

Dalam ruang lingkup NGO secara umum, terdapat berbagai macam bentukbentuk organisasi yang berbeda-beda di dalamnya. Bentuk-bentuk organisasi tersebut antara lain: (1) organisasi sukarela (voluntary organization atau VO); (2) organisasi rakyat (peopleorganizationatau $\mathrm{PO}$ ); (3) kontraktor pelayanan umum (public service contractor atau PSC); dan (4) organisasi non-pemerintah 'milik'pemerintah (govermment non-government atau GONGO) (Korten, 2002). 


\section{Teori Gerakan Sosial}

Secara teoretis terdapat teori gerakan sosial di luar teori gerakan yang berbasiskan idiologi Marxist.Walaupun teori lama tersebut sudah jarang digunakan sebagai bahan analisis gerakan sosial, tetapi tetap mempunyai sejarah sendiri dalam gerakan menuntut keadilan. Beberapa teori dalam gerakan sosial adalah sebagai berikut :

a. Teori Gerakan sosial Klasik/Lama

Dalam perspektif ini, beranggapan bahwa gerakan sosial lahir karena dukungan dari mereka yang terisolasi dan teralineasi di masyarakat. Gerakan sosial klasik ini merupakan cerminan dari perjuangan kelas di sekitar proses produksi, dan oleh karenanya gerakan sosial selalu dipelopori dan berpusat pada kaum buruh. Paradigma dalam gerakan ini adalah Marxist Theory, sehingga gerakan ini selalu melibatkan dirinya pada wacana idiologis yang meneriakkan 'anti kapitalisme', 'revolusi kelas' dan 'perjuangan kelas'.Orientasinya juga selalu berkutat pada penggulingan pemerintahan yangdigantikan dengan pemerintahan diktator proletariat.

b. Teori Gerakan Sosial Baru

Teori gerakan sosial baru adalah muncul sebagai kritik terhadap teori lama sebelumnya yang selalu ada dalam wacana idiologis kelas.Gerakan sosial baru adalah gerakan yang lebih berorientasi isu dan tidak tertarik pada gagasan revolusi.Tampilan dari gerakan sosial baru lebih bersifat plural, yaitu mulai dari gerakan anti rasisme, anti nuklir, feminisme, kebebasan sipil dan lain sebagainya. Gerakan sosial baru beranggapan bahwa di era kapitalisme liberal saat ini perlawanan timbul tidak hanya dari gerakan buruh, melainkan dari mereka yang tidak terlibat secara langsung dalam sistem produksi, misalnya ; mahasiswa, kaum urban, kaum menengah, karena sistem kapitalisme telah merugikan masyarakat yang berada di luar sistem produksi.

c. Teori Mobilisasi Sumber Daya

Dalam perspektif ini, gerakan sosial mensyaratkan sebentuk komunikasi dan organisasi yang canggih ketimbang terompet teriakan anti kapitalisme.Gerakan sosial muncul akibat adanya ketersedian sumber pendukung gerakan, tersedianya kelompok koalisi, adanya dukungan dana, adanya tekanan dan upaya pengorganisasian yang efektif, dan juga idiologi. Para teoretisi memobilisasi sumber daya mengawalitesis mereka dengan menolak penekanan pada peran perasaan dan penderitaan dan kategori-kategori psikologisasi dalam menjelaskan fenomena gerakan sosial.Teori Orientasi Identitas

\section{METHODS}

Jenis penelitian ini merupakan penelitian kualitatif deskriptif dengan pendekatan partisipatoris. Pendekatan partisipatoris diharapkan peneliti dapat mengungkap pengalaman, persepsi dan gagasan yang mendalam (Agustang. A, 2011) mengenai ; (1) perkembangan organisasi Muhammadiyah ; (2) bentuk gerakan sosial Muhammadiyah ; serta (3) transformasi sosial Muhammadiyah di Kabupaten Wajo.

Penelitian ini difokuskan pada gerakan sosial Muhammadiyah, termasuk perkembangan organisasi dan transformasi sosial Muhammadiyah, dengan lokus penelitian di Kabupaten Wajo Provinsi Sulawesi Selatan. Oleh karena itu, fokus utama dalam penelitian ini sebagaimana yang tertuang dalam rumusan masalah penelitian, yaitu ; (1) bagaimana perkembangan organisasi Muhammadiyah di Kabupaten Wajo ; (2) bagaimana bentuk gerakan sosial Muhammadiyah yang berbasis masyarakat di Kabupaten Wajo; (3) bagaimana dampak gerakan sosial Muhammadiyah terhadap proses transformasi sosial masyarakat di Kabupaten Wajo.

Untuk mengetahui hal tersebut, peneliti mengambil informasi dari informan dengan teknik purposive sampling, dari ciri-cirinya seperti : (1) sampel tidak ditentukan atau ditarik terlebih dahulu ; (2) sampel dipilih atas dasar fokus penelitian ; (3) sampel ditentukan oleh pertimbangan-pertimbangan informasi yang diperlukan, jika tidak ada lagi informasi yang dibutuhkan maka penarikan sampel dapat diakhiri (Agustang. A, 2015). Sampel tersebut terdiri atas ; (1) Pengurus Daerah Muhammadiyah Kabupaten Wajo, (2) Pengurus Cabang Muhammadiyah di Kabupaten Wajo, (3) warga Muhammadiyah dan simpatisan di Kabupaten Wajo, (4) pengelola amal usaha 
Muhammadiyah di Kabupaten Wajo, (5) tokoh-tokoh Muhammadiyah di Kabupaten Wajo khususnya dan di Sulawesi Selatan umumnya.

\section{RESULTS AND DISCUSSIONS}

Usaha dan kegiatan Muhammadiyah dapat dikelompokkan ke dalam tiga bidang, yakni:

\section{Gerakan Sosial dalam Bidang Agama}

Kajian Al-Islam dan Kemuhammadiyahan sangat diperlukan dalam rangka peneguhan ideologi bermuhammadiyah, dengan jalan merevitalisasi pemahaman yang terkandung dalam Muqaddimah Anggaran Dasar, Kepribadian dan Matan Keyakinan dan cita-cita hidup Muhammadiyah, Khittah, serta pedoman hidup islami warga muhammadiyah. Kajian ini banyak dilakukan diberbagai institusi persyarikatan termasuk amal usaha Muhammadiyah (AUM) dan perlu digerakkan secara lebih intensif sehingga berkualitas baik substansi maupun aplikasinya. Dengan demikian, akan semakin dipahami hakikat Al-Islam dan Kemuhammadiyahan secara komprehensif, sekaligus dapat dicegah kecenderungan sebagian aktivis dan warga muhammadiyah yang tertarik kepada faham lain yang berkembang di tengah masyarakat.

Peningkatan kualitas praktek ibadah sesuai dengan tarjih Muhammadiyah juga penting untuk diintensifkan disertai dengan peningkatan kekhuysukan dan fungsi kebaikan dari pelaksanaan ibadah mahdhah tersebut dalam kehidupan. Praktek ibadah mahdhah yang benar dapat menumbuhkan militansi dan menjadikan ciri khas yang membedakan cara beramal ibadah dengan mereka yang bukan Muhammadiyah, sekaligus menumbuhkan kesalihan individual dan kesalihan sosial yang fungsional bagi kehidupan yang tercerahkan. Pelatihan praktek ibadah, khususya ibadah madhah, sebagaimana tuntutan tarjih Muhammadiyah, sangat diperlukan bagi anggota Muhammadiyah.

Adatiga faktor yang menyebabkan pembinaan muballigh Muhammadiyah kurang maksimal, Pertama faktor ulamanya. Ulama Muhammmadiyah yang paham betul akan nilai yang diperjuangkan Muhammadiyah sudah sangat kurang ditemukan. Tidak istiqomah dalam menangani dakwah Muhammadiyah.Ulama Muhammadiyah sekarangpada umumnya tidak mau terikat dengan paham Islam Muhammadiyah.Faktor kedua, tidak bersinerji antara Majlis Tarjih dan Tabligh, Kedua majelis terlihat jalan sendiri.Padahal, sebagaimana diketahui bahwa sinergitas antara keduanya mutlak diperlukan.Tarjih sosialisasikan produk, Tabligh maksimalkan implementasinya.Faktor ketiga,mubailig.Para muballigh Muhammadiyah seringkali tidak bisa mengatur waktu karena faktor kesibukan, jika ada undangan memberikan ceramah atau khutbah Jum'at, seringkali ditolak dengan berbagai alasan.

Ulama adalah yang paling kompoten membicarakan agama.Ulama pewarisnabi. Ulama tercipta karena pemahaman, pengetahuan, dan perbuatannya sesuai ajaran Islam. Muhammadiyah hadir dan bertahan sampai sekarang, karena peran ulamanya.Ulama adalah salah satu identitas utama Muhammadiyah.Mubalig pun demikian, merekalah yang menyampaikan dakwah Muhammadiyah di lapangan.

Sekarang, ulama kurang diperhitungkan karena paradigma kepercayaan masyarakat bergeser dari ulama ke akademisi. Kondisi masyarakat secara umum memandang pemahaman sarjana lebih kompeten dibanding pemahaman ulama.Meski ulama sebetulnya yang paling kompeten membicarakan agama, sekarang tidak lagi, yang dianggap sekarang adalah ilmuwan.

\section{Gerakan Sosial dalam Bidang Pendidikan}

Gerakan sosial persyarikatan Muhammadiyah bidang pendidikan, yang meliputi pendidikan yang beroerientasi kepada perpaduan antara sistem pendidikan umum dan sistem pesantren. Visi penyelenggaraan pendidikan Muhammadiyah adalah tertatanya manajemen dan jaringan pendidikan yang efektif sebagai gerakan Islam yang maju, profesional dan modern serta untuk meletakkan landasan yang kokoh bagi peningkatan kualitas pendidikan Muhammadiyah. Misi penyelenggaraan pendidikan Muhammadiyah adalah (1) menegakkan keyakinan tauhid yang murni, (2) menyebarluaskan ajaran Islam yang bersumber kepada al-Qur'an dan as-Sunnah, (3) mewujudkan amal islami dalam 
kehidupan pribadi, keluarga dan masyarakat, (4) menjadikan lembaga pendidikan Muhammadiyah sebagai pusat pendidikan, dakwah dan perkaderan.

Dalam dunia pendidikan, Muhammadiyah, telah melakukan aktifitasnya dalam bentuk mendirikan madrasah-madrasah dan pesantren dengan memasukkan kurikulum pendidikan dan pembelajaran ilmu pengetahuan umum dan modern, mendirikan sekolahsekolah umum dengan memasukkan kurikulum keislaman dan kemuhammadiyahan. Lembaga pendidikan yang didirikan dikelola dalam bentuk amal usaha dengan penyelenggaranya Majelis Pendidikan Dasar dan Menengah (DIKDASMEN), secara vertikal mulai dari Pimpinan Pusat sampai ke tingkat Pimpinan Cabang.

Agar lembaga pendidikan Muhammadiyah dapat bertahan dan berjaya maka ada beberapa hal yang perlu diperhatikan :

1. Perekrutan sumber daya manusia untuk memikirkan pengembangan lembaga tersebut

2. Ada pendampingan dari konsultan pendidikan.

3. Lembaga pendidikan itu ada keunggulan yang merupakan karakteristik atau ciri yang tidak dimiliki lembaga lain.

4. Ada komitmen gerakan dari pimpinan daerah Muhammadiyah kabupaten Wajo beserta pengurus dan anggotanya.

Pada hakikatnya, lembaga pendidikan Muhammadiyah Kabupaten Wajo, ada potensi untuk maju, jika diperhatikan manaejemen, sumber daya, serta kerja sama dengan pihak-pihak yang pemodal dan simpatisan, dan perlu pemimpin yang memiliki visioner.

\section{Gerakan Sosial Muhammadiyah dalam Bidang Sosial Kemasyarakatan}

Muhammadiyah merupakan organisasi islam yang terkenal dalam gerakan pelayanan sosial dan kesehatan, bahkan dapat dikatakan sebagai pelopor. Tidak ada gerakan pembaruan islam di dunia ini yang merintis dan mengembangkan gerakan pelayanan sosial dan kesehatan yang melembaga hingga kini terus berkembang kecuali Muhammadiyah. Bagi Muhammadiyah, amal usaha di bidang sosial dn kesehatan merupakan gerak pemberdayaan sebagai perwujudan dari semangat teologi al-Ma'un yang dilembagakan melalui Penolong Kesengsaraan Oemoem (PKO)

Melayani kaum miskin, anak yatim dan kaum dhuafa lainnya merupakan panggilan keagamaan sebagai wujud dan konsistensi menjalankan agama, sebaliknya menelantarkan dan tidak peduli dengan kaum yang lemah itu merupakan bentuk dari pendustaan agama Islam. Beberapa Panti Asuhan di Sulawesi Selatan masih eksis sampai saat ini sebagai upaya gerakan tajdid dalam bidang al-Ma'un. Hal in telah menjadi program Pimpinan Muhammadiyah Sulawesi Selatan dan telah diimplementasikan hingga ke daerah-daerah.

Jumlah amal usaha Muhammadiyah dibidang kesehatan dan sosial yakni; 1 Balkesmas, 1 Panti Asuhan , 2 unit ambulance. Untuk meningkatkan pelayanan kesehatan dan pelayanan sosial, Majelis pembina kesehatan umum menjalin kerjasama dengan Kementrian Kesehatan RI khususnya dalam melaksanakan program EMAS dan Kabupaten Wajo merupakan salah satu daerah sasaran pendampingan.

Pengelolaan Panti Asuhan "Darussalam" Muhammadiyah Sengkang, saat ini dalam proses revitalisasi dengan pengembangan manajemen model pesantren. Jumlah anak binaan saat ini ada 37 orang, 14 orang pengurus/ pembina. Telah dibangun asrama putri lantai dua dengan bantuan dana dari pemerintah daerah Kabupaten Wajo melalui APBD tahun 2013. Selain itu, ada fasilitas laboratorium komputer dan internet sebanyak 6 unit komputer dari Kemenkominfo, pengadaan ruang belajar bersama (aula) dan mushallah

\section{Dampak Gerakan Muhammadiyah Terhadap Proses Transformasi Sosial Masyarakat di Kabupaten Wajo}

Pembahasan dan Pembicaraan tentang gerakan Muhgammadiyah dapat dibaca, didengar dan dilihat dari berbagai leteratur atau melalui pandangan para aktivis Muhammadiyah baik pada tingkat lokal maupun Nasional. Muhammadiyah sebagi 
sebuah persyarikatan telah merumuskan visi dan misi sehingga dapat mencapai tujuan yang diinginkan

Usaha dan kegiatan Muhammadiyah dalam bidang keagamaan yang meliputi memberikan tuntunan dan pedoman dalam bidang aqidah, ibadah akhlak dan muamalah berdasarkan al-Quran dan as-sunnah, mendirikan masjid dan musallah, mencetak kader ulama, menelaah berbagai kajian ke-Islaman dan perkembangan umat Islam, memberi fatwa dan tuntunan dalam bidang keagamaan dan dakwah. Ketiga Bidang sosial kemasyarakatan yang meliputi kegiatan dalam bentuk amal usaha rumah sakit, rumah bersalin, poliklinik, balai pengobatan, apotik, panti asuhan dan anak yatim.

Adapun dampak dari gerakan Muhammadiyah terhadap proses transformasi sosial masyarakat di Kabupaten Wajo, dapat dilihat dalam beberapa indikator, seperti a). Dalam bidang keagamaan (keyakinan), pelan tapi pasti masyarakat wajo memperoleh pencerahan terutama yang terkait dengan tahayul, bid'ah dan khurafat. Kini masyarakat Wajo pada umumnya dan warga Muhammadiyah pada khususnya lebih berpikir rasional dalam menyikapi hidup ini . b). Dalam bidang pendidikan, telah banyak mengubah paradigma berpikir msyarakat. Dari cara berpikir yang negatipdan sempit terhadap pendidikan berubah menjadi berpikir positip dan luas terhadap dunia pendidikan, namun karena keberadaan sekolah Muhammadiyah yang mengakomodir semua masyarakat yang ingin sekolah telah menyadarkan masyarakat betapa sekolah (pendidikan) itu penting dalam mengubah nasib, sabagaimana yang terdapat dalam al-Quran bahwa Sesungguhya Allah swt.tidakakan mengubah nasib satu kaum (bangsa) kecuali kauum (bangsa) itu sendiri yang mengubahnya apa-apa yang pada diri mereka (Quran: ar-Rad ayat 11) ; c). Dalam bidang sosial kemasyarakatan Muhammadiyah Daerah Kabupaten Wajo memberikan layanan prima bagi kaum dhuafa dan fakir miskin, Masyarakat merasa aman karena ada Muhammadiyah yang siap memberikan bantuan baik material maupun moral.

\section{E. CONCLUSION}

Perkembangan organisasi Muhammadiyah di Kabupaten Wajo pada awalnya tidak mendapat simpati di hati masyarakat.Masyarakat Wajo menganggap bahwa organisasi Muhammadiyah adalah organisasi yang dapat menghilangkan tradisi dan adat istiadat leluhur yang telah dianut masyarakat Wajo secara turun temurun, khususnya yang terkait dengan tahayul, bid'ah dan khurafat yang dikenal dengan istilah "TBC".

Bentuk gerakan sosial Muhammadiyah yang berbasis kemasyarakatan di Kabupaten Wajo, dapat diidentifikasi ke dalam tiga gerakan sosial, yaitu ; gerakan sosial dalam bidang dakwah, gerakan sosial dalam bidang pendidikan dan gerakan sosial dalam bidang kesehatan b). Dalam bidang pendidikan, organisasi Muhammadiyah telah banyak mendirikan lembaga pendidikan atau sekolah-sekolah, mulai dari jenjang Taman Kanakkanak (TK), sampai pada jenjang Sekolah Menengah Atas (SMA) ; c). Dalam bidang kesehatan, organisasi Muhammadiyah juga berkontribusi dalam mewujudkan klinik kesehatan dan atau Rumah Sakit Bersalin.Namun tidak dapat dipungkiri ketiga gerakan sosial yang selanjutnya menjadi amal usaha Muhammadiyah mengalami keterpurukan dalam kurung beberapa tahun terakhir.

Adapun dampak dari gerakan Muhammadiyah terhadap proses transformasi sosial masyarakat di Kabupaten Wajo, dapat dilihat dalam beberapa indikator, seperti ; a). Dalam bidang keagamaan (keyakinan), pelan tapi pasti masyarakat Wajo mendapatkan banyak pencerahan terutama yang terkait dengan tahayul, bid'ah dan khurafat. Kini masyarakat Wajo pada umumnya dan warga Muhammadiyah pada khususnya lebih berpikir rasional dalam menyikapi hidup ini ; b). dalam bidang pendidikan, telah banyak mengubah paradigm berpikir msyarakat. Dari cara berpikir yang negatif atau sempit terhadap pendidikan berubah menjadi berpikir positif dan luas terhadap dunia pendidikan. Jika dulu masyarakat berpendapat bahwa sekolah itu hanya layak untuk orang bangsawan dan turunannya atau kalangan tertentu saja, namun karena keberadaan sekolah Muhammadiyah yang mengakomodir semua masyarakat yang ingin sekolah telah menyadarkan masyarakat betapa sekolah (pendidikan) itu penting dalam mengubah nasib, sabagaimana yang terdapat dalam al-Quran bahwa Allah swt.tidak mengubah nasib satu kaum (bangsa) jika kaum (bangsa) itu tidak berusaha untuk mengubahnya ; c). Dalam 
bidang kesehatan, masyarakat telah sadar, betapa kesehatan itu sangat penting.Padahal sebelumnya masyarakat Wajo lebih percaya kepada dukun dalam berbagai urusan kesehatan.mulai urusan sakit perut sampai urusan melahirkan semua dibawa ke dukun. Tapi setelah organisasi Muhammadiyah membuka klinik kesehatan dan Rumah Sakit Bersalin, pelan tapi pasti masyarakat mulai lebih rasional dan mengobati penyakitnya di klinik atau Rumah Sakit Bersalin bila ada yang ingin melahirkan.

\section{DAFTAR PUSTAKA}

A.Pichardo, Nelson. 1997 New Social Movement 'A Critical Review'.California: Annual Review of Sociology. Vol. 33.

Abercrombie, N., S. Hill and B. S. Turner. 2000. 'Social structure' inThe PenguinDictionary of Sociology, 4th ed., Penguin, London, pp. 326-327.

Abercrombie, Nicholas, 2010. Kamus Sosiologi. Pustaka Pelajar: Yogyakarta

Aberle, David F. 1966. A Classification Of Sosial Movement.Chicago: Aldine Publishing Aberle Co

Adaby, Ahmad, Darban dan Mustafa Kemal Pasha.2000.Muhammadiyah sebagai Gerakan Islam (dalam perspektif Historis dan Ideologis) Yogyakarta : Pustaka Pelajar,

Agustang. A. (2011). Filosofi Research (Dalam Upaya Pengembangan Ilmu).

Agustang. A. (2015). Dasar-Dasar Filsafat Penelit(ian Untuk Pengembangan Ilmu (Idham Irwansyah Idrus (ed.); Pertama). CV Multi Globa, Jalan Maccini Sawah No. 251.

Agustang, A. (2011). Pendekatan Penelitian Kualitatif dan Kuantitatif Suatu Tinjauan Kritis. Makassar: Andira Publisher.

Agustang, A. (2007). Entaskan Kemiskinan: Analisis Kinerja Pembangunan Indonesia. Makassar: Indobis Publisher.

Agustang, A. (2018). SIMBOLIKHAJI: Studi Deskriptif Analitik pada Orang Bugis. AlQalam, 15(2), 317-334.

Agustang, A. (2017). Sufisme dan Kemiskinan Kultural pada Komunitas Nelayan di Pesisir Teluk Bone Kecamatan Sibulue.

Agustang, A. (2006). Defleksi Sosio-Kultural Masyarakat Maritim Ke Arah Kepentingan Pembangunan (Studi Kasus Pada Komunitas Nelayan di Kabupaten Selayar Provinsi Sulawesi Selatan). Disertasi. Program Pascasarjana Universitas Padjajaran. Bandung.

Agustang, A. (2020, October). Social Actions of Galla Actors in the Kaemba Maros Traditional Village Community Sulawesi Selatan. In 3rd International Conference on Social Sciences (ICSS 2020) (pp. 748-753). Atlantis Press.

Agustang, A. (2021, January 9). KESEJAHTERAAN PSIKOLOGIS (Studi Pada Dewasa Madya yang Belum Menikah di Kota Makassar). https://doi.org/10.31219/osf.io/v5af8

Agustang, A., \& Asrifan, A. (2021, January 9). BAHAN MATA KULIAH MATA KULIAH PSYCHOLINGUISTICS. https://doi.org/10.31219/osf.io/n8j6t

Agustang, A., Suardi, I. A. M., Mutiara, I. A., \& Ramlan, H. (2020). SOCIAL PRENEUR DALAM PENANGGULANGAN KEMISKINAN DI KECAMATAN BISSAPPU KABUPATEN BANTAENG. Martabe: Jurnal Pengabdian Kepada Masyarakat, 3(2), 331-342.

Agustang, A., ORUH, S., \& ASRIFAN, A. (2021). PENGARUH PENGETAHUAN KELUARGA, STIGMA MASYARAKAT DAN KEPATUHAN MINUM OBAT TERHADAP KEKAMBUHAN PENYAKIT GANGGUAN JIWA DI KOTA MAKASSAR. OSF Preprints. January, 9.

Astinah, A., Idris, R., \& Agustang, A. (2020). AGILE LEADERSHIP AND DIVORCE EDUCATION: STUDY ON WOMEN'S PERCEPTION. Humanities, 8(3), 323330 
Arwan, A., Agustang, A., Arlin, A., Yani, A., \& PUTRA, D. M. (2019). Contestation of Elite Discourse in Treatment of HIV and AIDS. Iranian Journal of Public Health, 48(12), 2205..

Bob S Hadiwinata, The Politics of NGOs di Indonesia : Developing Democracy dan Managing a Movement : 2003.

Bruce J Cohen, 1992.Sosiologi Suatu Pengantar, Jakarta, Rineka Cipta,

Damami, Muhammad, 2004.Akar Gerakan Muhammadiyah,Yogyakarta :Fajar Pustaka.

David. 2002. Menuju Abad ke - 21 : Tindakan Sukarela dan Agenda Global.Yayasan Obor Indonesia: Jakarta.

Edgar F. Borgatta, 1992. Marei L Borgotta (et.al), Encyclopedia of sociology. Volume 4 (New York :MacMillan Publishing Company,) hal 1880.

Edy Suandi Hamid (Ed) .2001. Rekontruksi Gerakan Muhammadiyah Pada Era Multi Peradaban.Yogyakarta : Pimpinan Pusat Muhammadiyah.

Gettys, W. E., et. 1989.Al. Classical Physics and Modern. Mc Grawn-Hill Book Company,

Giddens, Anthony. 1979. Cultural Problems in Social Theory. London: Macmillan

Heldman, D.R. and R.P. Singh. 2001. Introduction to Food Engineering. London:Academic Press.

Mutiara, I. A., Agustang, A., Adam, A., Upe, A., \& Equatora, M. A. (2020). The dynamics of prostitutes lives in metropolitan cities. Journal of Critical Reviews. https://doi. org/10.31838/jcr, 7, 165.

M, Hasim. 2006. Pendidikan Kewarganegaraan. Jakarta: Quadra

Pannyiwi, R., Agustang, A., Kasnawi, T., Pada, A. T., Yani, A., \& Syam, S. (2020). Social Network for Drug Circulation in Sidenreng Rappang Regency, Indonesia. Systematic Reviews in Pharmacy, 11(9), 575-577.

Rieuwpassa, S., Agustang, A., \& Adam, A. Sustainable Peace Development In Ambon (An Analysis Study In Negeri Hila And Dusun Hila Tanah Putih).

Sapulette, A. A., Agustang, A., \& Syukur, M. Actor Construction in the Frame of Diversity to Achieve Social Harmony in the Life of Tamilouw Village Society Seram Island-Maluku.

Tilome, A. A., Agustang, A., Jasruddin, M. S., \& Asrifan, A. (2020). Social Exchange of Political Elites in the Regional Leader Election of Gorontalo Province, Indonesia. Solid State Technology, 63(5), 521-531.

Upe, A., Salman, D., \& Agustang, A. (2019). The effects of the exploitation of natural resources towards risk society construction in Southeast Sulawesi Province, Indonesia. Journal of Degraded and Mining Lands Management, 6(2), 1587.

Awaru, A. O. T., Idris, R., \& Agustang, A. (2018, October). Sexual Education at High School Sinjai East. In 1st International Conference on Social Sciences (ICSS 2018). Atlantis Press.

Idris, M., Ramli, M., Agustang, A., \& Kesuma, A. I. (2015). Bureaucracy Ethics Based in Public Service Local Wisdom in Gowa. Mediterranean Journal of Social Sciences, 6(6 S4), 419-419.

Agustang, A., Pada, A. T., \& Bastiana, M. (2018, October). Social Interaction of Local Communities With Migrants and Changes in The Structure of Local Communities (Study on Plural Society in Makassar Industrial Area). In 1st International Conference on Social Sciences (ICSS 2018). Atlantis Press.

Wardah, S., Salman, D., Agustang, A., \& Fahmid, I. M. (2017). The Contestation of Organic and Non-Organic Agricultural Knowledge in Sustainable Agriculture. Mediterranean Journal of Social Sciences, 8(2), 245-245. 
Agustang, A. (2018). SIMBOLIKHAJI: Studi Deskriptif Analitik pada Orang Bugis. AlQalam, 15(2), 317-334.

Pannyiwi, R., Agustang, A., Kasnawi, T., Pada, A. T., Yani, A., \& Syam, S. (2020). Social Network for Drug Circulation in Sidenreng Rappang Regency, Indonesia. Systematic Reviews in Pharmacy, 11(9), 575-577.

Agustang, A., \& Soelthan, A. (2015). Analysis of the Inhibiting Factors of Transparency in the Implementation of Local Governance. Mediterranean Journal of Social Sciences, 6(6 S4), 464.

Nain, U., \& Agustang, A. (2020). Analysis On The Utilization Of Village Funds In Cash For Work Program In Bulukumba Regency, South Sulawesi Indonesia. International Journal of Advanced Science and Technology, 29(7s), 2811-2818.

Azis, F., Idris, R., \& Agustang, A. (2017). Involution Fisheries: Post-Study Model of National Program in Integrated Movement at Community Fishermen's Village Development Arungkeke, Jeneponto. Mediterranean Journal of Social Sciences, 8(1), 441.

Agustang, A. D. M. P., \& Nur, H. (2020). Konflik Mahasiswa Parang Tambung Universitas Negeri Makassar. Phinisi Integration Review, 3(1), 46-54.

Rasyid, R., Agustang, A., Maru, R., Agustang, A. T. P., \& Sudjud, S. (2020). PENYULUHAN PENCEGAHAN PENYALAHGUNAAN NARKOBA DI KALANGAN PELAJAR SMP NEGERI 6 DUAMPANUA KABUPATEN PINRANG. JMM (Jurnal Masyarakat Mandiri), 4(2), 116-123.

Rahmania, S., \& Agustang, A. (2017). PRESEPSI MAHASISWA FIK TERHADAP PENYIMPANGAN SEKSUAL LESBIAN (STUDI KASUS PADA MAHASISWA FIK UNM). JURNAL SOSIALISASI, 162-168.

Ashar, A., \& Agustang, A. (2020). Dampak Sosial Dana Desa Dalam Kesejahteraan Masyarakat Di Desa Kalola, Kecamatan Maniangpajo, Kabupaten Wajo. Jurnal Sosialisasi: Jurnal Hasil Pemikiran, Penelitian dan Pengembangan Keilmuan Sosiologi Pendidikan, (1), 19-25.

Yusuf, M., \& Agustang, A. (2020). DINAMIKA PERUBAHAN SOSIAL EKONOMI PADA MASYARAKAT KINDANG KABUPATEN BULUKUMBA. Jurnal Sosialisasi: Jurnal Hasil Pemikiran, Penelitian dan Pengembangan Keilmuan Sosiologi Pendidikan, (2), 31-37.

Fransina, M., \& Andi, A. (2019). THE ANALYSIS OF EXISTENCE OF MIGRATION IN THE CONTEXT OF BASUDARA COMMUNITY IN AMBON CITY, INDONESIA. Russian Journal of Agricultural and Socio-Economic Sciences, 94(10).

Usman, A., Agustang, A., Djalal, D., \& Annas, S. (2018, October). The Contribution Of Supporter Community In Maximizing Their Role For The Advancement Of Makassar Football Club (PSM). In 1st International Conference on Social Sciences (ICSS 2018). Atlantis Press.

Agustang, A., \& Oruh, S. Factors affecting of heropnam of mental disorders in Dadi Regional Hospital in South Sulawesi Province. Man In India, 97(11), 233-244. 
Pratiwi, E. L., \& Agustang, A. (2018). PERSEPSI ORANGTUA SISWA TERHADAP TINDAKAN GURU DALAM MENDISIPLINKAN SISWA DI SMK YPKK LIMBUNG. JURNAL SOSIALISASI, 6-10.

Asri, A., Kasnawi, T., \& Agustang, A. Actors' Social Tensions on Traditional Birth Attendants and Midwife Partnerships in Childbirth Assistance (Sociology of Health Study in Bulukumba Regency).

Bahri, S., Kasnawi, T., Agustang, A., \& Adam, A. (2017). Vegetarian Community Social Movement (Analysis of Health Sociology in Makassar). The Social Sciences, 12(10), 1824-1831.

Djalante, A., Agustang, A., Tahmir, S., \& Sahabuddin, J. A Disadvantaged Tribe in Bajoe Village, Bone Regency: A Phenomenological Research on Bajo Tribe's Social Life in Bone Regency, South Sulawesi.

Rahmawati, R., \& Agustang, A. (2018). PERBANDINGAN POLA ASUH ORANG TUA SISWA BERPRESTASI DENGAN SISWA YANG TIDAK BERPRESTASI DI SMA NEGERI 2 GOWA. JURNAL SOSIALISASI, 115-119.

Agustang, A. (2018). PERAN WALI KELAS DALAM PENYELESAIAN KONFLIK ANTAR SISWA DI SMA NEGERI 1 PINRANG. JURNAL SOSIALISASI, 12-16.

Irnawaty, I., \& Agustang, A. (2019). SMARTPHONE ADDICTION PADA MAHASISWA PENDIDIKAN SOSIOLOGI FAKULTAS ILMU SOSIAL UNIVERSITAS NEGERI MAKASSAR. JURNAL SOSIALISASI, 41-46.

Zainuddin, M., \& Agustang, A. (2019). KONTROL SOSIAL ORANGTUA TERHADAP PENGGUNAAN SMARTPHONE PADA REMAJA (STUDI DI DESA GIRING-GIRING KECAMATAN BONTONMPO KABUPATEN GOWA. JURNAL SOSIALISASI, 68-73.

Sofyan, Y., \& Agustang, A. (2018). PENERAPAN MODEL PEMBELAJARAN KOOPERATIF TIPE NHT (NUMBERED HEADS TOGETHER) TERHADAP $\begin{array}{llllllll}\text { KEAKTIFAN BELAJAR } & \text { SISWA } & \text { KELAS } & \text { XI } & \text { IPS } & 1 & \text { SMAN } & 8\end{array}$ MAKASSAR. JURNAL SOSIALISASI, 158-165.

Agustang, A. (2018). PENERAPAN PUNISHMENT DALAM MEMBENTUK KARAKTER DISIPLIN SISWA DI SMA NEGERI 1 TAKALAR. JURNAL SOSIALISASI, 126-130.

Amiruddin, T. K., Agustang, A., \& Idris, R. (2014). RELIGIOUS CONVERSION IN MARRIED LIFE IN MAKASSAR, THE CASE OF CHRISTIANITY TO ISLAM. JOURNAL OF ACADEMIC RESEARCH, 6(6), 264.

Machmuddin, H., Agustang, A., Kahar, F., \& Bustan, N. (2015). IMPROVING THE QUALITY OF PRIMARY HEALTH SERVICES IN THE PERSPECTIVE OF PARTICIPATORY GOVERNANCE. International Journal of Academic Research, 7(1).

Agustang, A., \& Sahabuddin, J. (2020, October). MODEL KOLABORASI SOSIAL PENDIDIKAN KARAKTER DI SEKOLAH SWASTA KECAMATAN BISSAPPU KABUPATEN BANTAENG. In PROSIDING SEMINAR DAN DISKUSI PENDIDIKAN DASAR. 
Astinah, A., Idris, R., \& Agustang, A. (2020). AGILE LEADERSHIP AND DIVORCE EDUCATION: STUDY ON WOMEN'S PERCEPTION. Humanities, 8(3), 323330.

Muis, I., Agustang, A., \& Adam, A. (2020). Elderly Poverty: Social Demographic, Work Distribution, Problem Health \& Social Protection. Asian Journal of Social Sciences \& Humanities Vol, 9(1).

Agustang, A. (2020). Symbolic Violence towards Students in the Context of the Existence of the Stereotypical Frames of Lecturers and Students in the Higher Education System in Indonesia. PalArch's Journal of Archaeology of Egypt/Egyptology, 17(2), 249-258.

Asrifan, A. (2009). Using songs in teaching English language for the young learners. ParePare: unpublished.

Puasa, K., Asrifan, A., \& Chen, Y. (2017). Classroom Talk in Bilingual Class Interaction. Research in Pedagogy, 7(1), 106-121.

Nadirah, N., Tahir, M. H., \& Asrifan, A. (2019). THE ABILITY TO TRANSLATE ENGLISH PHRASES INTO INDONESIAN AND THE DIFFICULTIES FACED BY THE ELEVENTH GRADE STUDENTS OF SMAN 1 PANCARIJANG. JOURNAL OF ADVANCED ENGLISH STUDIES, 2(1), 41-46.

Apdy, A. P. R., \& Asrifan, A. (2019, April). The Chinese mime game in teaching vocabulary on EFL classroom. In PROCEEDINGS OF THE 65th TEFLIN INTERNATIONAL CONFERENCE (Vol. 65, No. 01).

Taslim, T., Asrifan, A., Chen, Y., \& Nurdania, N. R. (2019). CORRELATION BETWEEN STUDENT'S VOCABULARY MASTERY AND SPEAKING SKILL. JOURNAL OF ADVANCED ENGLISH STUDIES, 2(2), 65-76.

Muthmainnah, M., Asrifan, A., Al Yakin, A., \& Sahabuddin, C. (2019, April). The use of dictogloss technique on ELT classroom: An experiment study of students listening comprehension. In PROCEEDINGS OF THE 65th TEFLIN INTERNATIONAL CONFERENCE (Vol. 65, No. 01).

Mutmainnah, M., Azis, S., Maulidya, U., \& Asrifan, A. (2017). Glory Style in Mandar Song Lyrics: A study of Mandar Tribe in South Sulawesi, Indonesia. JOURNAL OF ADVANCES IN LINGUISTICS, 8(1), 1286-1291.

Asrifan, A., Rinantanti, Y., Tang, S., \& Nadirah, N. (2019). THE 3-DIMENSION PICTURES IN INCREASING THE STUDENTS ABILITY AND INTEREST TO WRITE DESCRIPTIVE COMPOSITION. JOURNAL OF ADVANCED ENGLISH STUDIES, 2(1), 19-30.

Asrifan, A., Nadira, N., \& Haedar, H. (2018). IMPROVING STUDENTS'READING COMPREHENSION OF DESCRIPTIVE TEXT THROUGH COLLABORATIVE MURDER. JOURNAL OF ADVANCED ENGLISH STUDIES, 1(2), 21-31.

Asrifan, A. (2015). Analysis of English Students' Learning Style in Bilingual Class. International Journal of Literature and Arts, 3(4), 34. 
Farahdiba, S., \& Asrifan, A. (2016). Speaking Ability and Psychological Barriers of the Second Year Students of Hotel Department of SMKN 1 Sidenreng Kabupaten Sidrap in Speaking English. Asian EFL Journal, (89), 41.

Asrifan, A. (2012). Increasing the Students Ability to Write Descriptive Composition at SMP Negeri 13 Parepare by using the 3-Dimension Pictures.

Tang, S., Asrifan, A., Chen, Y., Haedar, H., \& Agussalim, M. (2019). THE HUMOR STORY IN TEACHING READING COMPREHENSION. JOURNAL OF ADVANCED ENGLISH STUDIES, 2(2), 77-87.

Nurwanti, N., Asrifan, A., \& Haedar, H. (2019). THE APPLICATION OF COOPERATIVE LEARNING: JIGSAW II TECHNIQUE IN IMPROVING STUDENTS'READING COMPREHENSION OF EXPOSITORY TEXT. JOURNAL OF ADVANCED ENGLISH STUDIES, 2(1), 31-40.

Asrifan, A. (2016). The Effectiveness of Think-Pair-Share Technique in Improving Studentsâ $€^{\mathrm{TM}}$ Speaking Ability and Interest. English Literature and Language Review, 2(3), 24-35.

Asrifan, A., Muthmainnah, M., Al-Yakin, A., Sahabuddin, C., \& Haedar, H. (2018). THE CAUSE-EFFECT TECHNIQUE IN TEACHING RECOUNT WRITING. JOURNAL OF ADVANCED ENGLISH STUDIES, 1(2), 63-72.

Asrifan, A., Vargheese, K. J., Syamsu, T., \& Amir, M. (2020). ESP COURSE DESIGN: THE NEED ANALYSIS ON TOURISM DEPARTMENT IN INDONESIA VOCATIONAL HIGH SCHOOLS. JOURNAL OF ADVANCED ENGLISH STUDIES, 3(2), 69-77.

Asrifan, A., Ghofur, A., \& Azizah, N. (2020). Cheating Behavior in EFL Classroom (A Case Study at Elementary School in Sidenreng Rappang Regency). OKARA: Jurnal Bahasa dan Sastra, 14(2), 279-297.

Nadirah, N., Asrifan, A., Vargheese, K. J., \& Haedar, H. (2020). INTERACTIVE MULTIMEDIA IN EFL CLASSROOM: A STUDY OF TEACHING READING COMPREHENSION AT JUNIOR HIGH SCHOOL IN INDONESIA. JOURNAL OF ADVANCED ENGLISH STUDIES, 3(2), 131145.

Muthmainnah, A. R., Atmowardoyo, H., Salija, K., \& Asrifan, A. (2020). Literary Work as Teaching Materials: A Study of Students and Lecturers Needs Analysis. Solid State Technology, 63(5), 394-407.

Tilome, A. A., Agustang, A., Jasruddin, M. S., \& Asrifan, A. (2020). Social Exchange of Political Elites in the Regional Leader Election of Gorontalo Province, Indonesia. Solid State Technology, 63(5), 521-531.

Pacinongi, A., \& Asrifan, A. (2020). Bimbingan Pengawas Berkelanjutan dalam Mewujudkan Pendidikan Karakter Bangsa dalam Kegiatan Belajar Mengajar Penjaskes. Celebes Education Review, 2(1), 1-7.

Gunawan, G., \& Asrifan, A. (2020). Penerapan Kerja Kelompok Kegiatan MGMP Guru Ekonomi dalam Menyusun RPP untuk Meningkatkan Kompetensi Pedagogik. Celebes Education Review, 2(1), 31-36.

Yusuf, I., \& Asrifan, A. PENINGKATAN AKTIVITAS KOLABORASI PEMBELAJARAN FISIKA MELALUI PENDEKATAN STEM DENGAN 
$\begin{array}{lllllll}\text { PURWARUPA } & \text { PADA SISWA } & \text { KELAS } & \text { XI IPA } & \text { SMAN } & 5\end{array}$ YOGYAKARTA. Editorial Team, 32.

Al Yakin, A., Sahabuddin, C., Rahayu, A., Fitrah, N., \& Arifin, M. (2020). Political Celebrification and Electability: A Study of Political Phenomena Imaging in Election Polewali Mandar District, West Sulawesi, Indonesia. Solid State Technology, 63(5), 632-646.

Junaedah, S. B. T., \& Ahmad, M. A. (2020). The Outdoor Learning Modules Based on Traditional Games in Improving Prosocial Behaviour of Early Childhood. International Education Studies, 13(10).

Octaberlina, L. R., \& Muslimin, A. I. (2020). Efl students perspective towards online learning barriers and alternatives using moodle/google classroom during covid19 pandemic. International Journal of Higher Education, 9(6), 1-9.

Octaberlina, L. R., \& Anggarini, I. F. (2020). Teaching vocabulary through picture cards in Islamic Elementary School: a case study in Nida Suksa School, Thailand. Jurnal Madrasah, 13(1), 26-38.

Octaberlina, L. R. (2016). Plagiarism in English language theses in Indonesia. Jurnal Ilmu Pendidikan, 14(3).

Octaberlina, L. R., \& Anggarini, I. F. (2020). Teaching vocabulary through picture cards in Islamic Elementary School: a case study in Nida Suksa School, Thailand. Jurnal Madrasah, 13(1), 26-38.

Asrifan, A., Zita, C. T., Vargheese, K. J., Syamsu, T., \& Amir, M. (2020). THE EFFECTS OF CALL (COMPUTER ASSISTED LANGUAGE LEARNING) TOWARD THE STUDENTS'ENGLISH ACHIEVEMENT AND ATTITUDE. JOURNAL OF ADVANCED ENGLISH STUDIES, 3(2), 94-106.

Asrifan, A. (2021). ACADEMIC WRITING. LawArXiv. January, 2. https://doi.org/10.31228/osf.io/x2s7e

Asrifan, A. (2020). TUTORIAL PENGGUNAAN QUIZIZZ (www. quizizz. com) PADA PEMBELAJARAN. https://doi.org/10.31219/osf.io/kqnza

Asrifan, A. (2021). Abd Ghofur.“. THE USE OF READING CIRCLES IN INCREASING STUDENTS SPEAKING ABILITY AT THE ELEVENTH GRADE SMK NEGERI, 1. https://doi.org/10.31219/osf.io/8vjxy

Asrifan, A. (2020). Pandemic, Humanity and Education. https://doi.org/10.31219/osf.io/q2gpk

Asrifan, A. (2021). USING CAT AND MOUSE GAME TO IMPROVE STUDENT'S SPEAKING ABILITY AT THE ELEVENTH GRADE OF MA YMPI RAPPANG. https://doi.org/10.31219/osf.io/phtvn

Asrifan, A., \& Ghofur, A. (2021). THE USE OF READING CIRCLES IN INCREASING STUDENTS SPEAKING ABILITY AT THE ELEVENTH $\begin{array}{llll}\text { GRADE } & \text { SMK } & \text { NEGERI } & 1\end{array}$ PANCARIJANG. https://doi.org/10.31219/osf.io/8vjxy

Asrifan, A. (2021). Book Review: Halliday. 1989. Spoken and Written Language. Oxford University Press. https://doi.org/10.31219/osf.io/ej8tb 
Asrifan, A., \& Ghofur, A. (2021). TALK, ACTION, SILENCE, INTERRUPTION AND THEIR IMPLICATIONS IN BUGINESE SOCIETY (SOPPENG REGENCY). https://doi.org/10.31219/osf.io/pv3ku

Asrifan, A. (2020). PENILAIAN BERBASIS ANDROID MENGGUNAKAN APLIKASI PLICKERS. https://doi.org/10.31219/osf.io/htreq

Haulussy, R. H., Najamuddin, I. R., \& Agustang, A. D. M. P. (2020). The sustainability of the Sasi Lola tradition and customary law (Case study in Masawoy Maluku, Indonesia). Intl J Sci Technol Res, 9(2), 5193-5195.

Arwan, A., Agustang, A., Arlin, A., Yani, A., \& PUTRA, D. M. (2019). Contestation of Elite Discourse in Treatment of HIV and AIDS. Iranian Journal of Public Health, 48(12), 2205.

Mutiara, I. A., Agustang, A., Adam, A., Upe, A., \& Equatora, M. A. (2020). The dynamics of prostitutes lives in metropolitan cities. Journal of Critical Reviews. https://doi. org/10.31838/jcr, 7, 165.

Usman, A., Agustang, A., Djalal, D., \& Annas, S. (2018, October). The Contribution Of Supporter Community In Maximizing Their Role For The Advancement Of Makassar Football Club (PSM). In 1st International Conference on Social Sciences (ICSS 2018). Atlantis Press.

Ma'na, P., Agustang, A., Salusu, J., Ikhsan, A., \& Dirawan, G. D. (2015). Decision making strategic value based local wisdom Tongkonan North Toraja. Man India, 95(3), 633-639.

Dirawan, G. D. FOSTERING COLLABORATION STREET CHILDREN IN MAKASSAR. Man In India, 95(3), 569-576.

Abdurachman, A. D. M. P. A., \& Agustang, A. Culture Of Shame-Heart And Social Solidarity Of Kaitetu People Central Maluku District, Indonesia.

Aida, K. N., Agustang, A., Arlin, A., \& Agustang, A. D. M. The Patron-Client Relationship Patterns In Siwa Lima Fishermen Community, Aru Islands District Maluku, Indonesia.

Pannyiwi, R., Agustang, A., Kasnawi, T., Pada, A. T., Yani, A., \& Syam, S. (2020). Social Network for Drug Circulation in Sidenreng Rappang Regency, Indonesia. Systematic Reviews in Pharmacy, 11(9), 575-577.

Upe, A., Salman, D., \& Agustang, A. (2019). The effects of the exploitation of natural resources towards risk society construction in Southeast Sulawesi Province, Indonesia. Journal of Degraded and Mining Lands Management, 6(2), 1587.

Matakena, F., Watloly, A., Agustang, A., Adam, A., \& Alim, A. (2020). The SelfConcept of Ale Rasa Beta Rasa in the Orang Basudara Community in Ambon (Studies on the Community of Passo and Batumerah Country). International Journal, 9, 1307.

Asmi, A. S., Kasnawi, M. T., Agustang, A., \& Yani, A. (2020). Sociocultural Transformation in Efforts to Reduce Mortality of Infants in Bone Regency, Indonesia. Systematic Reviews in Pharmacy, 11(10), 762-765.

Usmana, A., \& Agustangb, A. The Implementation of "Arif" Social Behaviour within Perssin Supporters in Sinjai District. 
Hasan, I. R., Agustang, A., Kahar, F., \& Tahir, H. (2019). Super Service Delivery": an advanced conceptual model of one-stop service for wide administrative region. Problems and perspectives in management, (17, Iss. 1), 189-201. 